\title{
1. Introduction to Constitutional Crowdsourcing
}

This is a text about democratic legitimacy, participation, and decision-making in constitutions and constitutionalism. In it, I have conceptualised a new phenomenon, "constitutional crowdsourcing". I also go on to analyse how the participation of the people can be included in constitutional making and constitutional interpreting, that is, in the exercise of original and derived constituent power. I believe that constituent powers' typology overcomes the mere standard juristic account (to express the distinction between the act of founding and the conferred power to amend the constitution). ${ }^{1}$ The real sovereigns interpret the constitution in order to have the last word on all constitutional issues.

Truth be told, constitutional crowdsourcing's epistemic construction gives content and provides a signifier to an old aspiration consisting of the attribution to the people (the crowd) of the supreme power and authority in constitutionalism. In this sense, and following Saussure's well-known distinction, to scrutinise the signified implies the revision of an old political issue, co-substantial to the dimension of politics since the establishment of the first democratic institutions during the fifth century BC and revisited throughout history by several classes of polities, culminating in the birth of modern constitutionalism. The historical account also evidences the innovative and revolutionary character of constitutional crowdsourcing, providing a new dimension and introducing new elements to this matter because of its epistemic relation with digitalisation and the network society. ${ }^{2}$

1 Martin Loughlin (2013) "The Concept of Constituent Power", available online $<$ www.law.utoronto.ca/utfl_file/count/users/mdubber/CAL/12-13/Loughlin-Paper -Constituent\%20Power.pdf $>$ accessed on 19 March 2021.

2 From the library on popular constitutionalism: Sanford Levinson (2006) Our Undemocratic Constitution: Where the Constitution Goes Wrong, Oxford: Oxford University Press; Mark Tushnet (1999) Taking the Constitution Away from the Courts, Princeton: Princeton University Press; John Ferejohn, Jack Rakove and Jonathan Riley eds (2001), Constitutional Culture and Democratic Rule, Cambridge: Cambridge University Press; Larry Kramer (2004) The People Themselves: Popular Constitutionalism and Judicial Review, Oxford: Oxford University Press; Frank Michelman (1999) Brennan and Democracy, Princeton: Princeton University Press; Antoni Abat i Ninet (2013) Constitutional Violence, Legitimacy, Democracy and Human Rights, Edinburgh: Edinburgh University Press. 
The book conceives constitutional crowdsourcing as an epistemic response, an opportunity to place the people at the heart of constitutionalism in the new digital era. ${ }^{3}$ Thus, the current concept of crowdsourcing, mainly defined as an online crowd phenomenon, is I believe a limitation of its nature, and offline crowds must have and must participate in decision-making in the constitutional-legal domain.

The book aims to answer the research question: how can crowdsourcing strengthen or weaken democratic constitutionalism in the network society? To answer this question, the book explores the people's role in constitutional making and constitutional interpreting. After reviewing the people's role in constituent power, the thesis that the book supports is that crowdsourcing can strengthen democratic constitutionalism because it reinforces the democratic legitimacy of the constitutional text. By overcoming the strict bilateral relationship between representatives and the represented (them and us), constitutional crowdsourcing opens popular debate and deliberation on political institutions, constitutional principles, and dispositions of the state. There is no need for a relationship of allegiance when "we" and not "they" are the drafters of the constitution. This symbiosis implies a deeper degree of openness and the inclusion of ideas and projects that have been silenced for several reasons, such as elitist-class interests. A question that creeps up is whether this symbiosis also implies the right to revoke the representatives; I do not believe so, however it is necessarily a new distribution of powers.

As Chapter 4 illustrates, constitutional crowdsourcing reinforces political equality (isonomos and isegoria); I believe that popular constitutionalism can be an opportunity to mediate political conflicts, to engage peace processes and transitions to democracies. Placing the people at the constituent process's core promotes public education (paideia) and active citizenship. Regarding the risks that popular constitutionalism implies, the book discusses "institutional/ official deviation", consisting of the risk of institutional exploitation of a constitutional crowd, or the abuse of popular constitutional making, to protect particular social or economic interests. Another risk is based on an elitist conception that considers the people lacking in legal knowledge, assuming the masses to be legal illiterates (i.e., they do not know the legal language), or supposing a need for institutional guidance to end a constituent process successfully. Other risks point to the idea that popular constitutionalism produces never-ending constitutions and a sort of "wish list".

The concept of constitutional crowdsourcing has increasing theoretical relevance in multiple disciplines. The literature so far has explored the concepts of 
network society and digitalisation and the legal implications of the Internet on legal systems, legal knowledge, and political relations. There is also an incipient field of knowledge and research that links artificial intelligence, digitalisation, and public law and the impact of the IT revolution on fundamental rights and freedoms. This book is part of this new field of knowledge and, despite presenting a transdisciplinary perspective, it is focused on constitutions, constituent process, and constituent power (original and derivate).

In the analysis of such topics, there is a gap that this book aims to fill concerning the role that the people may develop in the exercise of constituent power in the digital era. The book is an original theoretical/epistemological construction that aims to take advantage of the huge opportunities that the digital era generates, also in the field of law and politics, to give constituent power to its constitutionally entitled sovereign: the people. The book takes the perspective of legal pluralism, avoiding a state-centred approach.

However, the book also aims to have practical relevance. It will set out some guidelines for adjusting democratic constitutionalism to the network society. Those guidelines will enhance opportunities and minimise risks. Chapter 4 exemplifies this practical significance by analysing the Chilean constituent process in light of the opportunities and risks explained in the book and comparing it with other constituent processes that have included democratic aspects to achieve democratic legitimacy.

After this introduction and the "fake judgment" between Aristos and Demos that aims to provide historical context to the concept of constitutional crowdsourcing, the book is structured according to two main research goals: conceptualisation and analysis of the crowd in the constituent process. Chapters 2 and 3 are devoted to the epistemic construction and de-construction of the components of the concept of constitutional crowdsourcing. Chapter 2 scrutinises the concept of "crowd", a phenomenon that has mutated from its ancient origin to its twenty-first-century version, including virtual, online, and smart crowds. The chapter follows historicism as the methodology and, more concretely, the principle of development that states that all human activities and institutions change and evolve in history and should be understood within a development process. In other words, the concept of the crowd in Plato or Machiavelli affects our understanding of smart crowds today and predisposes our acceptance to include or exclude crowds in constitutional decision-making.

A second axis is devoted to analysing determinant legal, political, and philosophical theories that lighten the role of the crowd in the constitutional domain. The current constitutional attributions to "the people", despite textual attributions and solemn proclamations, have been determined by historical happenstance. In this sense, the perspective used in this section is historicist, which brings to light some of the past debates and contradictions that have not been solved. The historical account also evidences the innovative and revolu- 
tionary character that the concept of constitutional crowdsourcing implies and the opportunities that the network society opens.

Chapter 2 divides the concept of the crowd into two kinds, traditional (offline) and online. This segmentation is based on a fundamental element of distinction, the means of access to the crowd and of the crowd (as corps politique). The difference is relevant because the current concept of crowdsourcing is mainly defined as an online crowd phenomenon. Despite this principal reduction of the term, I believe that constitutional crowdsourcing needs to include the possibilities that offline crowds offer to decision-making in the constitutional-legal domain.

Chapter 3 is related to the analysis of the concept of social network and includes some of its constitutional implications. The network society is a dynamic and open system, capable of evolving and expanding. This new digital and societal reality hides enormous implications, opportunities, and challenges; it affects how we traditionally have understood constitutions; constitutionalism and constitutional democracies are not an exception.

The network society has also generated expectations in law, democracy, and constitutionalism, with prospects ranging from online participation, deliberation, and popular decision-making to digital constitutions, digital citizenship, and digital public spheres, even digital justice automated judges. Some of the traditional foundations of these legal and political concepts need to be updated in the new era. How is it possible to apply Sieye's theories on constituent power to cyberspace? Is there any sense to the well-known distinction between pouvoir constituant originaire and pouvoir constituant dérivé on the Internet and new forms of global and multilevel (Verfassungverbund) constitutionalism? Chapter 3 aims to answer these questions.

After an epistemic construction/deconstruction, the book explores the application of popular constitutionalism, and more concretely, democratic constituent power. Chapter 4 is devoted to the role that people have developed and currently develop in the making of a constitution. Participation of "the people" in constitutional making has evolved throughout the near three centuries of modern constitutionalism, ranging from a null participation at the very origins of modern constitutionalism to a role of constitutional ratifier (referendum), later to develop a significant role in participatory constitutionalism, and ending with the people as constitutional makers.

The last section deals with the opportunities and risks that constitutional crowdsourcing implies and the prospect that the experience from comparative constitutional law generates to new constituent processes, such as the one currently being developed in Chile.

A complete analysis of a theory dealing with constitutional crowdsourcing needs to address the potentialities that this phenomenon has in the domain of constitutional interpretation, a sphere that modern constitutional democracies 
have attributed exclusively to constitutional courts and councils in continental systems or to the judiciary in common law systems. Or, as Werhan remarks: "the popular constitutionalism project is nothing less than an appeal that the People, or their elected representatives, replace the Court as the day-to-day decision-maker regarding the meaning and application of the Constitution". 4

Chapter 5 deals with these aspects following Mark Tushnet's "mandate" of taking the constitutions away from the Courts. It starts by adopting a historical methodology and reviews several examples of popular participation in constitutional interpretation in antiquity, remarking on some of the arguments to ground and consolidate the reservations and limitations on the people in this domain. The experiences of the dikasteria or places of justice, the graphe paranomōn, and the theoretical concept of nomophilakes (Guardians of the Constitution) are relevant to our purposes in this chapter, even though these ancient institutions need to be contextualised within the diverse reality that Athens experienced in the times of Solon and Pericles and related to our digital times.

I propose the implementation of existing digital tools and platforms (Estonian KIS and i-voting) to improve current democratic measures existing in the domain of constitutional control (Bolivia, Japan, Cuba, US state constitutionalism, the political constitution of the City of Mexico). The goal is to promote a progressive implementation of constitutional crowdsourcing in constitutional control institutions using network society's potentialities. The last segment of Chapter 5 is a proposal for a constitutional jury as an e-dikasteria.

\section{THE JUDGMENT}

After the failed Icelandic experience of constitutional crowdsourcing (2009-2012), members of the state's legal community, parliamentarians, and policymakers affirmed that the constitutional draft proposed by the constitutional council of 25 citizens and approved unanimously on 27 July 2011 was unrealistic, unenforceable, and against the legal and political tradition of the Nordic country. According to these legal experts, the final approval of that constitutional draft would have plunged the country into a lack of legal certainty. The fully ex-novo character of the constitution would also disenable judges from using jurisprudence to resolve the legal penumbras created by the text's potential application. The people of Iceland focused excessively on the constitutional accommodation of human rights, leaving aside other essential factors that a constituent process might include. On the other hand, other legal

4 Keith Werhan (2012) "Popular Constitutionalism, Ancient and Modern", 46 University of California Davis Law Review 68. 
experts have argued that the state's main institutions, political parties, and the economic and intellectual elite betraying the will of the people provoked the failure of the first crowdsourced constitutional experience.

This judgment marks how revolutionary and innovative the constitutional crowdsourcing experience is.

\section{(Demos v. Aristos)}

Demos is represented by Pericles, Aristos by Thucydides. Claims are made in the applications and submissions presented by the parties. In its application, the following claims were made by Demos, "to accept constitutional crowdsourcing as a normative constituent process to be able to define our political systems legitimately as constitutional democracies" and "to consider Aristos as uniquely responsible for the failure of the Icelandic constitutional crowdsourced experience".

Based on the facts and legal arguments presented by his representatives, Aristos respectfully requests the participants of the Court to adjudge and declare that the constitutional crowdsourcing method cannot be considered a form of constituent process because of the danger of giving the common people the draft of Politiea, the basic and most important legal norm of the state. It also requests from the Court a declaration of responsibility against Demos in the Icelandic experience.

\section{Historical and factual background}

Pericles in representation of the plaintiff has expressed the following facts: The plaintiff first wants to clarify that current constitutional systems cannot be defined as "democracies". States and constitutions are using the term "democracy" to define themselves in the maintenance of a purely fictional notion. Our current "democratic" systems, in the best-case scenario, are republics, representative democracies, or polyarchies (Dahl). The plaintiff bases its argument on three main lines of argumentation: (1) the mistrust in Demos' capabilities in politics is unjustified and comes from different events throughout history; (2) the concept of Demos as "we the people" is an inclusive concept, and there is no discrimination of any sort; and (3) Aristos is using Politeia to protect caste interests. The cases of constitutional crowdsourcing serve as empirical evidence of these facts, and they exemplify how Aristos prioritises class and particular interests over the public good.

The plaintiff states that the tension that we see today is a long-standing issue; that the relationship between the parties has been fluctuating and changes according to concrete historical period and place. However, at present, when there are more "democracies" worldwide than ever before, and when constitutional democracy is considered the best possible system, the definitive 
involvement of Demos into the constitutional realm is not only desirable but necessary. The representative of Demos remarks that if Demos is not included today in the constitutional sphere, it is for several reasons, some of them related to an ancient mistrust that modern Aristos does not hesitate to exploit.

The list of grievances is long, too long to be compelled in a judicial claim, but in order to exemplify this phenomenon, Solon remarks on three different moments: (a) the birth of the democratic system and the first political classifications and hierarchies; (b) the foundation and legal juridification of the first modern "constitutional republics" in the United States in 1776 and in France in 1789; and finally, (c) the attribution of liability to democracy for allowing the victory of Nazism and Fascism in Germany, Italy, Austria, and also later in Portugal, Spain, Greece, Hungary, Romania, and Albania, and a systemic weakness in defending against new terrorist threats.

Since its appearance, Demos has been held as suspicious and undesirable by the political and economic elites that originally ruled the Attican city-states. In this sense, Solon, Demosthenes, Ephialtes, and Cleisthenes (the champions of democracy $)^{5}$ introduced democratic measures against the rule of a King or Aristos. Solon, with the cancellation of indebtedness and the mortgages of landholding citizens, demonstrated that democracy is related to a quantitative number of rulers and a qualitative reason. Ephialtes giving sovereignty to the people in the implementation of a new tribal organisation system, creating the council of five hundred and reducing the role of the aeropagus, demonstrated how difficult it was to implement democratic improvements in a political system that was already conceived for and by a ruling elite.

Regardless of democratic measures that have allowed more people to participate in the political decision-making process without discrimination, a democratic measure does not exclude the ruling elite because Aristos is also a constitutive part of Demos. On the contrary, Demos is not part of Aristos, and the opposition of all democratic improvements in ancient Athens and the twenty-first century are focused on protecting castes' and political parties' interests.

From the beginning, democracy has been criticised from both qualitative and quantitative perspectives. According to detractors, democracy cannot work qualitatively because the ignorant and passionate masses cannot deal with questions that require a certain degree of proficiency and knowledge. Quantitatively, democracy is inadequate because many people making deci-

5 Mogens Herman Hansen (1991) The Athenian Democracy in the Age of Demosthenes, Norman: University of Oklahoma Press; Martin Ostwald (1986) From Popular Sovereignty to the Sovereignty of Law, Oakland: University of California Press; Charles Howard McIlwain (2007) Constitutionalism: Ancient and Modern, Indianapolis: Liberty Fund. 
sions necessarily results in uncertainty, instability, and extreme additional difficulty in making decisions.

The evidence of these charges are the first classifications of political systems. Plato, Aristotle, Polybius, and Cicero placed democracy under other forms of government, Kingship and Aristocracy, and defined the system as a bad form of government. The role and placement of democracy in these classifications, which we are still analysing centuries later, is relevant for this Judgment because it evidences the mistrust in Demos' capabilities and because these political classifications are categorising political systems defined as Politeia (constitutions).

The polities' classifications started with Plato, who distinguished six types, organised in pairs: kingship and tyranny; aristocracy and oligarchy; and bad and good democracy. Plato considered that of constitutions, there are two mother forms, from which we can rightly say that the others have been derived. One of these we may adequately call monarchy and the other democracy. In the case of democracy, the Platonic classification states some of Aristos stereotypes to protect his own interests. The well-known myth of the cavern and the need of a Philosopher King to guide the blind masses to see the light of knowledge and exit from the cavern of ignorance plays a central role. As we will see later in this Judgment, this is translated to the Icelandic parliamentarians, and the philosopher-kings must guide the ignorant Icelandic inhabitants in the drafting of the modern Politeia.

Aristotle also used the term "constitution" to refer to the different forms of government. Politeia related to the nature of man as a political being, zoon politikon ( $\zeta \_$ov $\pi \mathrm{o} \lambda \iota \tau$ เóv), and the word "constitution" generally meant the form of government of man as a political animal. In the third book of the Politics, we also find the renowned classification of constitutions, in which the political power from the aristocracy will be transformed into oligarchy, then into tyranny, and then transitioned towards democracy. Even when Aristotle demonstrated less hostility to the concept of democracy than Plato, he also theoretically favoured aristocracy against democracy. ${ }^{6}$ The accusations and disfavour towards Demos continued in the work of Cicero and Polybius.

These classifications have placed democracy under other political forms of government for centuries, and centuries later, the framers of the first modern written constitution of the world opted for a Republican (mixed system) after studying the texts of Plato, Aristotle, Plutarch, Cicero, and Polybius, among others. The second relevant moment that the plaintiff remarks as an example of the continuous mistrust in Demos is related to the foundation of the first "con-

6 Carrie-Ann Biondi (2007) “Aristotle on the Mixed Constitution and its Relevance for American Political Thought”, 24(02) Social Philosophy and Policy 176. 
stitutional republic" in 1776 and the distinction that the French revolutionaries made between Nation and Demos.

The myth of Plato's cave creates a skewed distrust against my representative. Specifically, this has occurred in the role played first by the Supreme Court and then by Icelandic parliamentarians in blocking the constitutional process and preventing the approval of the constitution drafted and approved by the people. It can also be seen in the manipulation and use of citizen participation by President Bachelet in Chile, or the role played by the Mexican Supreme Court in annulling the possible participation of the citizens of the capital in their constitutions (federal, not state) as provided for in Article 37 of the political constitution of Mexico City in 2017.

The decision made by the framers of the American constitution of 1776, to establish a mixed constitution instead of a constitution through a popular executive power, has been crucially important for the rest of the constitutional systems around the world. The federalists were aware of the transcendence of the moment. In this sense, Alexander Hamilton considered the founding moment as determinant in knowing "whether societies of men are really capable or not of establishing good government from reflection and choice, or whether they are forever destined to depend for their political constitutions on accident and force". ${ }^{7}$ As we do in this trial, we analyse the possibilities of enabling Demos to participate actively and without intermediaries in the drafting and interpreting of a constitutional text. The first constituent process is relevant to this, as the ancient melody played by Plato and Cicero sounded strongly and clearly in the elites that monopolised the process in the United States.

The constitutive documents of the new country in the United States were written and thought up by wealthy white men who feared democracy. The Federalist Papers have been consolidated over time by an elite class of academics, judges, and lawyers, excluding and dismissing the fundamental rights of the "others", such as the working class, Native Americans, African Americans, and other minorities. A literal interpretation of Madison's famous words on factions in The Federalist Papers, 10, 14, and 49 will be enough to demonstrate the doubts of the Founding Fathers about the role of the Demos in politics or Locke reference to landholders and not democratic citizens. ${ }^{8}$

The fallacy has continued. Constitutional texts around the world are using the terms "democracy", "popular", and "We the people", instead of particracy, aristocracy, or representatives. There are some exceptions, in which the text 
says "We, the representatives of the people" (Ecuador or Argentina). But Article 1.2 of the Italian Constitution of 1947, Article 3.1 of the Portuguese Constitution of 1976, and Article 1.2 of the Spanish Constitution of 1978, as well as the preambles of 'we the people' in the United States of America, the Republic of South Africa, the Republic of India, and the Republic of Korea are good examples of this constitutional delusion.

According to all these texts, there is only one legitimate sovereign, the people, and therefore another subject of sovereignty (Aristos) is unconstitutional. If a constitutional text declares, 'we the people, from whom all powers come', then a de facto relocation of sovereign power is unconstitutional. This constitutional inaccuracy came onto the scene more severely when Demos was denied the right to draft the constitutional text. In these concrete examples, the usurpation of sovereignty breaches not only the preamble (politically, but not juridically, binding), but also constitutional dispositions. Besides this unconstitutionality, Aristos has introduced new juridical concepts, new rules, and theories to prevent a possible application of these constitutional articles and principles, such as the notion of the "programmatic articles", meaning that some concepts, the ones that Aristos decides, are not legally enforceable as such.

Another element used to build up suspicion of the role the plaintiff can play in politics is the distinction between the people and the nation established during the French Revolution. After the revolution, the nation was a group of citizens with political power and sovereignty. There is overlap between the concepts of nation, people, and the state to which the nation delegates its sovereignty. In the new French Republic, the sovereign is the nation, because according to Sieyès and Montesquieu, democracy was not possible in France due to the quantitative issue. The nation is the organised people, and to these arguments it can be added that there is no nation without people. But the paradox came when the concept of nation was instituted to include and protect the interests of the third estate. Aristos misinterpreted this to distinguish the terms of sovereignty, the nation, and the people. The principle of national sovereignty is, according to Carré de Malberg, the foundation of the modern state. It implies evolution and transformation of the exercise of power by difference with the monarchical principle and the principle of popular sovereignty. It is based on a representation of the sovereign nation. ${ }^{9}$

The plaintiff considers that this shows how the concept of nation was used to justify a republic and not a democracy, when national sovereignty as an

9 Éric Maulin (2002) “Carré de Malberg et le droit constitutionnel de la Révolution”, 328 Annales historiques de la Révolution française 5. 
abstract concept requires the mediation of representative institutions to be effective. The result is again to exclude Demos in favour of the representatives.

The weak democratic commitment of the revolutionaries is also expressed in the Declaration of the Rights of Man and of the Citizen of Paris 1789. In this predominant legal and political text, there is only a reference to "the people" in the preamble, "the representatives of the French people, organised as a National Assembly". It follows this by declaring in Article 3 that, "the principle of all sovereignty resides essentially in the nation. Nobody may exercise any authority which does not proceed directly from the nation" and concludes by affirming in Article 16, "a society in which the observance of the law is not assured, nor the separation of powers defined, has no constitution at all", avoiding any democratic reference or link to the concept of constitution.

A transcendent moment demonstrating the mistrust against Demos is the widespread accusation of its responsibility for the rise of Nazism and Fascism. The claim highlights as arguments the work of Hannah Arendt on totalitarianism, the denaturalisation of individuals, and the aesthetic negativity in Horkheimer and Adorno, Neumann, and Kirchheimer, the loss of freedom in Marcuse and Fromm, among others, to show the lack of responsibility of Demos.

The plaintiff refuses any sort of responsibility for the hijacking of the concept and essence of democracy by totalitarian regimes. He also quotes Jennifer Gandhi, Abel Escribà, and Adam Przeworski, among others, to demonstrate that dictatorships use democratic institutions to obtain political stability and increase the survival chances of the authoritarian regime. Even though the applicant denies any responsibility, he responds to the accusation, stating that from 1952, several legal systems have improved mechanisms to protect democratic institutions, just like the Militant Democracy. These mechanisms also solve Popper's paradox of democracy and majority rule.

In German constitutional law, Militant Democracy protects the liberal democratic order (freiheitlich-demokratische Grundordnung). This order is the fundamental basis of the German constitution and describes the basic principles of the moral values and political structures on which the liberal and democratic state of law is established. ${ }^{10}$ This protection is even more important when political parties have consolidated their hegemony in politics and mediated the public constitutional organs. As early as the 1930s, sociologists Karl Loewenstein and Karl Mannheim were thinking about a democratic construct they called streitbare Demokratie, which can be roughly translated into Militant Democracy. Their theories, which were based on the undermining of

10 Eckart Thurich (2011) Pocket Politik Demokratie in Deutschland, Roggentin: Bundeszentrale für politische Bildung, Vertrieb IBRO Versandservice. 
the democracy in the Weimar Republic by the Nazis, were kept in mind during the drafting of the Basic Law. ${ }^{11}$

Militant Democracy allows limitations on freedom of speech, political participation, and political pluralism while leaving core values unalterable. The limitation of certain fundamental rights seems to be justified based on the protection of a democratic system. Two conflicting ideas generate this democratic paradox. Firstly, the idea that a democracy is based on the free market of ideas, where every party is entitled to express its opinion and to participate in equal conditions to the rest of the parties, and second, the idea that a democracy is entitled to defend itself against its enemies. ${ }^{12}$

Roughly speaking, the concept of Militant Democracy refers to the fact that political parties cannot use democratic tools (democratic participation and benefits) to destroy democracy. The theory was initiated after World War II with the decision of the German Federal Constitutional Court of 1952 on the Socialist Reich Party. According to the Court, a political party may be removed from the political process only if it rejects the supreme principles of democracy. ${ }^{13}$ A similar theory has been applied in other countries. In some cases, the submission of political parties to democratic standards has been constitutionalised, while in others it has been set in an ad hoc law or developed by the judiciary.

With this background on the origins of democracy, the plaintiff considers that in current representative democracies, republics, the only way to reconcile Demos and Aristos is by introducing and progressively improving direct democratic tools into the system. In the new technological era, ${ }^{14}$ e-democracy offers a new range of possibilities to implement and improve direct democracy. From an epistemological perspective, e-democracy ends the "size" counter-argument against democracy, according to which in big states it was not possible to apply direct democratic tools. Among all the potential direct democratic tools, Demos considers constitutional crowdsourcing as the most transcendent because it affects Politeia and will redress the use of Nomos by Aristos against Demos.

In 2015, we saw the celebration of the 800th anniversary of the promulgation of the Magna Carta, an example of the use of Nomos in favour of Demos.

11 Karl Mannheim (1943) Diagnosis of Our Time: Wartime Essays of a Sociologist, Oxford: Routledge \& Kegan Paul; Karl Loewenstein (1937) "Militant Democracy and Fundamental Rights, I", 31 The American Political Science Review 423.

12 Suzie Navot (2008) "Fighting Terrorism in the Political Arena: The Banning of Political Parties" 14 Party Politics 746.

13 Donald P. Kommers (1997) The Constitutional Jurisprudence of the Federal Republic of Germany, Durham (NC): Duke University Press, 219.

14 Castells, supra note 3. 
It is a good moment to recover its spirit in constitutional matters. The Icelandic case shows how Aristos denies this possibility using the same ancient arguments that have been exposed briefly in the plaintiff's claim. Aristos cares for democratic progress in a second term; his first concern is and has always been to maintain caste benefits and interests.

\section{Thucydides in the representation of the respondent}

The response to the complaint deals with the same facts highlighted by the applicant in its legal claim and ended by noting why Demos cannot be included in the constituent process without the lead of the representatives. First, the representation of Aristos wants to express his complete opposition to the facts and claims of Demos. The interpretation exposed in the claim can be defined as democratic despotism because of its fervent and too-uncritical adherence to the doctrine of the sovereignty of the people.

The claim does not distinguish between different sorts of democracy (representative and direct), it simply limits democracy to the direct rule of the people. This dogmatic restriction does not allow the definition of a democratic regime with some way of attributing every major political decision to the people, either because they take part in making it, or because it depends on their consent. ${ }^{15}$ In this sense, the restrictions on the Icelandic constitutional crowdsourcing format disabled any sort of political party or parliamentarian participation in the process following this definition of the dogmatic rule.

According to the plaintiff, in a very Schmittean reductionism of political alternatives, there is only democratic friend - enemy, democracy, or authoritarianism. Paradoxically, the definition that Demos is using of democracy is also very Schmittean. The respondent does not need to remark Schmitt's role in the Nazi regime and his lack of democratic commitment. ${ }^{16}$ As the claim goes, Schmitt defines democracy as a state form and a governmental or legislative form where there is identity of ruled and ruler, governing and governed, commander and follower. ${ }^{17}$ This definition precludes the possibility that inside the democratic state the distinction of ruler and being ruled produces a qualitative difference. ${ }^{18}$

Consequently, the power or authority of those who rule may not be based on some higher qualities that the people do not easily obtain. This sort of equality

\footnotetext{
15 Roger Scruton (1982) A Dictionary of Political Thought, London: Macmillan, 131.

16 Yves Charles Zarka (2005) Un détail nazi dans la pensée de Carl Schmitt, Paris: Presses Universitaires de France.

17 Carl Schmitt (2008) Constitutional Theory, Durham (NC): Duke University Press, 264.

18 Ibid.
} 
will mean homogenisation and therefore will end up destroying difference and freedom. It also denies any recognition to those who are specialised and intellectually more prepared; capable of making concrete decisions that benefit the majority and require expertise and knowledge. Schmitt's definition follows the conceptualisation of democracy that appeared in the ancient political classifications that the plaintiff exposes.

The claim seems to forget that these classifications were based on Sparta's real political experiences and other city-states of the Attica. The claim of Demos also omits that democratic experiences have always failed and that the response to such democratic claims was authoritarianism.

According to the respondent, democracy is regarded as fatally flawed, in that it allows the ignorant masses to determine public policy - which in his view is a specialised function that should be properly performed only by the few men of philosophic talent who had been selected in youth and trained for the task. ${ }^{19}$ Democracy tends to undermine the expertise necessary to govern societies. In a democracy, he argues, those who are expert at winning elections and nothing else will eventually dominate democratic politics. ${ }^{20}$ Democracy tends to de-emphasise the expertise that is necessary to govern societies. This is because most people do not have the talents that enable them to think well about politics' problematic issues. ${ }^{21}$

When discussing constitutional tasks, the respondent considers it necessary to remark the distinction between democracy as the government of opinion (doxa) instead of that of knowledge (episteme). Plato supplies a mathematical reinforcement by proposing a straight line divided into two equal parts, one part representing the visible order, the other the intelligible, each part divided again in the same proportion, symbolising degrees of comparative clearness or obscurity. In other words, and as applied to our case, to draft a constitution requires episteme ( $\left.\dot{\varepsilon} \pi \_\tau \eta \dot{\mu \eta}\right)$, something that the Demos lacks.

The claim follows the accusations against the drafters of the Constitution of the United States of America. The respondent agrees that the framers opted for a mixed system after studying the texts of Plato, Aristotle, Plutarch, Cicero, and Polybius, among others, and after analysing the traumatic experiences of purely democratic constitutions. The first goal of the drafters was to assure political stability (Mikte). The best choice, if not the most unique, was clearly to build up a constitutional republic instead of a democracy, meaning inev-

19 Scott Gordon (1999), Controlling the State: Constitutionalism from Ancient Athens to Today Cambridge (MA): Harvard University Press, 76.

20 Plato (2006) The Republic, New York: Penguin Classics.

21 Tom Christiano (2018) "Democracy", Stanford Encyclopedia of Philosophy, $<$ https://plato.stanford.edu/archives/fall2018/entries/democracy/> accessed 21 March 2021. 
itably the failure of the new political project. This failure would have more devastating effects than the French revolutionary fiasco because the United States of America's Constitution was jurifying a new state.

The applicant's argument is a pure anachronism and does not take into account the effects of the war of independence and the tension between the northern and southern states. The plaintiff does not mention that one of the principal defendants of Demos' role instead of Aristos at the onset of the French Revolution was Robespierre, who justified a reign of terror in which tens of thousands were executed. Robespierre's speech of 5 February 1794, is an allegation in favour of "democracy", and he states that terror was a consequence of the general principle of democracy. ${ }^{22}$

The Jacobins' commitment and alliance with Demos also appear in Article 25 of the French Constitution of 1793, defining popular sovereignty (in the sense of population as the sum of all individuals) as opposed to national sovereignty (nation as an abstract body) that appeared in the French constitution of 1791. The respondent also considered it necessary to remark how successful in democratic terms have been the constitutions and states where Demos was defined as a unique sovereign in terms of "popular republic", such as the Soviet constitutions, the Constitution of the People's Republic of China, or the constitution of the Democratic People's Republic of Korea, where Article 2 of the constitution of 1948 disposed that the state power of the Republic belongs to the "people". The Green Book of Gaddafi too urged for direct democracy, while Mao Zedong affirmed in his opening address as Chairman of the Chinese Communist Party, at the First Plenary Session in 1949, that the Chinese system is a people's democratic dictatorship. ${ }^{23}$

Aristos refuses responsibility for allowing the rise of authoritarian regimes through democratic channels. The answer proposed by the plaintiff to Popper's democratic paradox consists in Militant Democracy and respect of human rights as a new co-substantial element of democracy. But democracy was a prominent idea among democratic politicians of the Weimar Republic, ${ }^{24}$ and democracy seems not to be prepared to give a proper answer to the new threats in Europe, such as le Front National in France, the Dansk Folkeparti in Denmark, Vox in Spain, the popular association Golden Dawn in Greece, or the neo-Nazi Togetherness-National Party in Slovakia. Other "democratic"

22 Maximilien Robespierre (2009) Discours par Maximilien Robespierre - 17 Avril 1792-27 Juillet 1794, Gutenberg E-books, available online <http://www.gutenberg .org/files/29887/29887-h/29887-h.htm> accessed 21 March 2021.

23 Mao Zedong (1949) "The Chinese People have Stood Up!", available online $<$ https://china.usc.edu/Mao-declares-founding-of-peoples-republic-of-china-chinese -people-have-stood-up> accessed 21 March 2021.

24 Schmitt, supra note 17, 266. 
experiences have allowed the rise of illiberal Islamist movements such as the Muslim Brotherhood in Egypt. All these cases seem to show that Popper's paradox is not solved at all, but, on the contrary, Demos cannot deal with some political and legal topics without the "correction factor" of Aristos.

The contradiction is even greater because Militant Democracy is, in its very essence, undemocratic. In other words, democracy is protected by undemocratic measures applied and decided by non-democratic institutions, such as constitutional courts. The European Court of Human Rights (ECtHR) has repeatedly stated that the Militant Democracy principle is limited to extreme cases. $^{25}$ The claim does not mention the problems that direct, immediate democracy could raise in the context of highly pluralistic and differentiated societies that are not exposed, and the Demos seems to think that they could be solved with recourse to e-democracy, as it is maintained that from an epistemological perspective, e-democracy ends the "size" counter-argument against democracy.

\section{The Verdict}

The dikasteria formed by the juror-readers of this book is competent to issue sentence on this judgment. However, as an author, I understand that I must cast my own vote, which must be considered as one among an indefinite number of jurors. Accordingly, I condemn Aristos as responsible for the failure of popularly rooted constitutionalism experiences, considering this kind of new constitutionalism as an inevitable, legitimate, and necessary constituent process.

25 European Court of Human Rights (ECtHR) in (1998) United Communist Party of Turkey v. Turkey, App no 19392/92 and (2009) Herri Batasuna and Batasuna v. Spain, App no 25803/04 and 25817/04. 